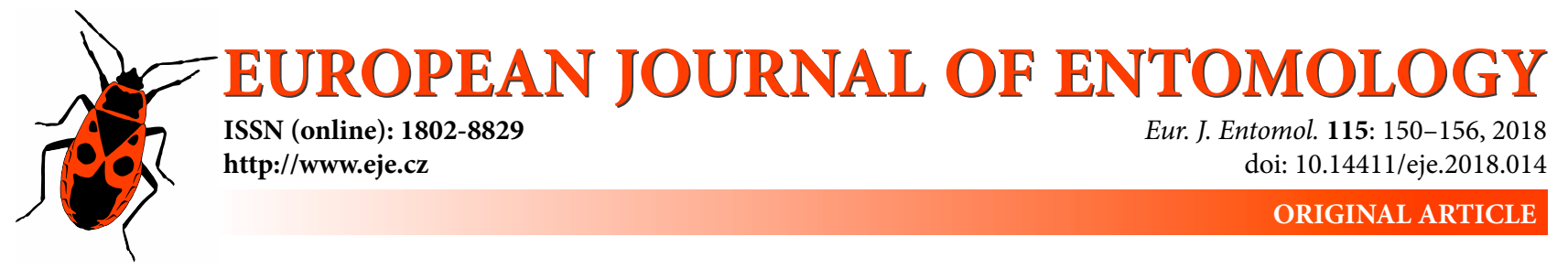

\title{
Efficiency of two methods of sampling used to assess the abundance and species diversity of adult Syrphidae (Diptera) in mountainous meadows in the Austrian and Swiss Alps
}

\author{
Raja I. HUSSAIN ${ }^{1}$, Ronnie WALChER ${ }^{1}$, David BRANDL ${ }^{1}$, Arne ARNBERGeR ${ }^{2}$, Johann G. ZALLER ${ }^{1}$ \\ and THOMAS FRANK ${ }^{1}$ \\ ${ }^{1}$ University of Natural Resources and Life Sciences, Department of Integrative Biology and Biodiversity Research, \\ Institute of Zoology, Vienna, Austria; e-mails: raja.hussain@boku.ac.at, ronnie.walcher@gmx.at, davidbrandl81@gmail.com, \\ johann.zaller@boku.ac.at, thomas.frank@boku.ac.at \\ 2 University of Natural Resources and Life Sciences, Institute of Landscape Developments, Recreation and Conservation \\ Planning (ILEN), Vienna, Austria; e-mail: arne.arnberger@boku.ac.at
}

Key words. Diptera, Syrphidae, hoverflies, sampling methods, observation-plot, line-transect, alpine grassland

Abstract. The outcome of assessments of the biodiversity of a taxonomic group often depend on the sampling method. The choice of an adequate method is especially important for biomonitoring purposes. In this study, the effectiveness of two methods of sampling syrphids (Diptera: Syrphidae) is compared: observation plot method vs. line transect, both sampled by sweep netting. Altogether, 18 meadows were selected in three mountain regions in the Austrian and Swiss Alps. We recorded a significantly higher abundance and richness of syrphids using the observation plot method than the line transect method in 2015. Comparing data for one region recorded in 2015 and 2016, similar results were obtained. Syrphid species assemblages were affected by sampling method in both years. More syrphid species and individuals were recorded using the observation plot method, which makes it more suitable for studies aiming at comparing differences in the numbers of adult syrphids in different grassland habitats.

\section{INTRODUCTION}

Biodiversity assessments for prioritizing conservation targets often rely on species inventories (Pimm et al., 1995). In addition to biodiversity assessments, species inventories also facilitate environmental monitoring, i.e. by comparing results of standardized sampling methods (Kohlmann, 2011). In selecting the taxa to be sampled, priority must be given to a group that has an important role in the structure and function of the target ecosystem (García-López et al., 2011). Syrphids (hoverflies) are used frequently to assess biodiversity (Ricarte \& Marcos-García, 2008; Petanidou et al., 2011) and functional diversity (Schweiger et al., 2007) of a variety of ecosystems. They are important agents of biological control and pollination (Haenke et al., 2009; Petanidou et al., 2011) and are also used as bioindicators (Burgio \& Sommaggio, 2007).

The effectiveness of sampling methods has a strong effect on the quantification of adult syrphid communities (Namaghi \& Husseini, 2009). Depending on the aim of the study, several methods can be used for sampling adult syrphids, including yellow pan traps, Malaise traps and hand nets. Hickman et al. (2001) report that only hungry syrphids flew around yellow pan traps. If the syrphids are not hungry there is no reason for them to be attracted by yellow pan traps (Namaghi \& Husseini, 2009). Similarly, Cane et al. (2000) cautions that this type of trap may not accurately reflect the diversity of pollinators and is the least effective method of sampling adult syrphids. The line transect (Sommaggio, 1999; Haenke et al., 2009) and the observation plot methods (Frank, 1999), which are both sampled using sweep nets, are used to record adult syrphid abundance and richness.

Therefore, we tested the effectiveness of the line transect and the observation plot methods in alpine meadows in Austria and Switzerland, which are known to harbour a large diversity of syrphids (Hussain et al., 2017). These two methods were used because they are suitable for use in alpine meadows. Moreover, these methods were studied because they are regularly used but usually separately (Frank, 1999; Sobota \& Twardowski, 2004; Marcos-García et al., 2012; Mudri-Stojnić et al., 2012; Power et al., 2016; Walcher et al., 2017). The aim of the present work was to determine which of these two sampling methods recorded the most species and individuals of adult syrphids. Moreover, we investigated whether the species assemblages re- 

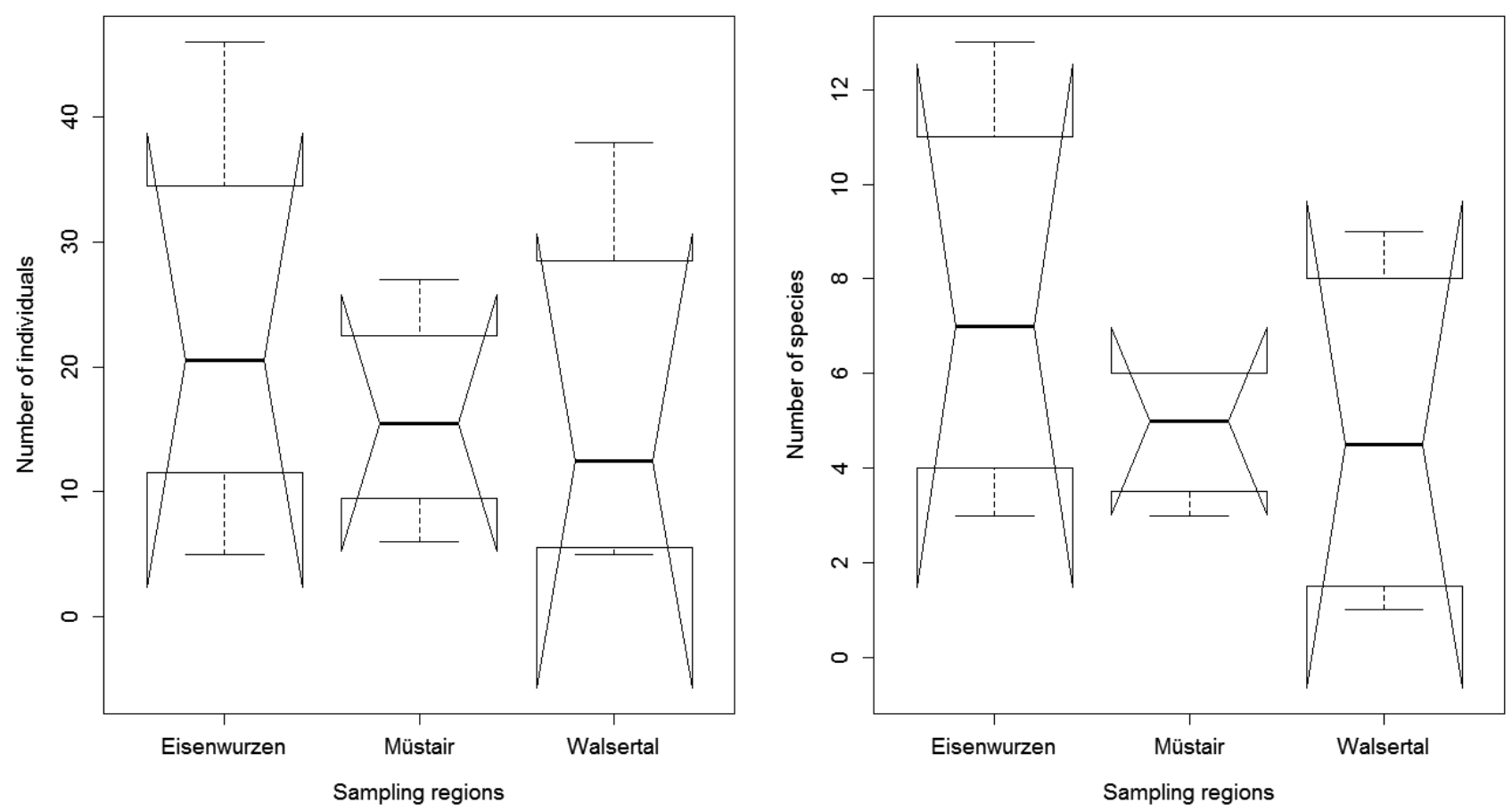

Fig. 1. Syrphid abundance and richness in three regions of Austria and Switzerland in 2015.

corded using these two methods were similar or differed significantly from each other.

\section{MATERIAL AND METHODS}

\section{Study regions}

This study was carried out in June and August 2015 in three regions in the Austrian and Swiss Alps (Table 1). The study sites were alpine meadows located in the regions of Eisenwurzen (Styria, Austria), Großes Walsertal (Vorarlberg, Austria) and Val Müstair (Graubünden, Switzerland) (Walcher et al., 2017). Altogether, six meadows (dominated by the grasses Bromus erectus, Brachypodium pinnatum and Molinia caerulea) with similar vegetation and located on south-facing slopes, were selected in each region $(6 \times 3=18$ meadows $)$. The average size of the meadows ranged between 300 and $5150 \mathrm{~m}^{2}$. There was no significant difference between the size of meadows in the three regions (ANOVA: $\mathrm{F}=2.27, \mathrm{p}=0.138$ ). Each meadow was surrounded by forest and an open landscape. At Eisenwurzen, the study region with a particularly high number of syrphids in 2015 (Fig. 1), the comparison of the two sampling methods was repeated in 2016 in order to strengthen the validity of the data.

\section{Sampling methods}

Syrphid species richness and abundance were surveyed using two different methods: line transects and observation plots. For the line transect method, three transects were established in the center of each study site. We made 30 sweeps per transect giving $3 \times 30=90$ sweeps per study site. Each transect was $15 \mathrm{~m}$ long and $2 \mathrm{~m}$ wide and the distance between each transect was $10 \mathrm{~m}$. Sampling was carried out by experienced people and consisted of walking in straight lines with a sweep net (opening diameter 40 $\mathrm{cm}, 1 \mathrm{~m}$ bar length). Along with line transects, four $2 \mathrm{~m}^{2}$ observation plots were established in a straight line at $0 \mathrm{~m}, 3 \mathrm{~m}, 9 \mathrm{~m}$ and $27 \mathrm{~m}$ distance per meadow. Observations were recorded over a period of $15 \mathrm{~min}$ for each plot. During the observations, every syrphid that visited a flower was recorded or collected using a sweep net if it was not possible to identify it on site. The frequency with which a sweep net was used in the observation plots depended on the number of unknown syrphids visiting a plot. There were four observation sessions ( $60 \mathrm{~min}$ per meadow) both in June and August 2015 when weather conditions were suitable, i.e. minimum temperature $15^{\circ} \mathrm{C}$ (temperature is a limiting factor for adult syrphid activity (Mudri-Stojnić et al., 2012), no rain or wind, dry vegetation and sunshine. The time of sampling was restricted to between 10 a.m. and 5 p.m. when syrphids are most active visiting flowers and was carried out by the same people, that is, they had the same experience of identifying syrphids. The two methods were carried out simultaneously in each meadow, therefore, field conditions during sampling were identical for both methods. Specimens that could not be identified were killed using ethyl acetate, transferred to plastic vials and brought to the

Table 1. Sites and their regional characteristics along an altitudinal gradient in Austria and Switzerland where Syrphids were sampled.

\begin{tabular}{|c|c|c|c|c|c|c|}
\hline Country & Region & Municipality & $\begin{array}{l}\text { Mean temperature } \\
\text { in June and August }\end{array}$ & $\begin{array}{l}\text { Mean annual } \\
\text { precipitation }\end{array}$ & Altitude a.s.l.* & GPS coordinates \\
\hline Austria & Eisenwurzen & $\begin{array}{c}\text { St. Gallen } \\
\text { Stainach } \\
\text { Pürgg } \\
\end{array}$ & $19^{\circ} \mathrm{C}$ & $1087 \mathrm{~mm}$ & $660 \sim 790 \mathrm{~m}$ & $\begin{array}{l}47^{\circ} 41^{\prime} \mathrm{N}, 14^{\circ} 37^{\prime} \mathrm{E} \\
47^{\circ} 32^{\prime} \mathrm{N}, 14^{\circ} 06^{\prime} \mathrm{E} \\
47^{\circ} 31^{\prime} \mathrm{N}, 14^{\circ} 03^{\prime} \mathrm{E} \\
\end{array}$ \\
\hline Austria & Großes Walsertal & Buchboden & $22^{\circ} \mathrm{C}$ & $1630 \mathrm{~mm}$ & $1180 \sim 1250 \mathrm{~m}$ & $47^{\circ} 14^{\prime} \mathrm{N}, 09^{\circ} 57^{\prime} \mathrm{E}$ \\
\hline Switzerland & Val Müstair & $\begin{array}{l}\text { Tschierv } \\
\text { Valchava } \\
\text { St. Maria }\end{array}$ & $24^{\circ} \mathrm{C}$ & $810 \mathrm{~mm}$ & $1740 \sim 1800 \mathrm{~m}$ & $\begin{array}{l}46^{\circ} 36^{\prime} \mathrm{N}, 10^{\circ} 20^{\prime} \mathrm{E} \\
46^{\circ} 36^{\prime} \mathrm{N}, 10^{\circ} 24^{\prime} \mathrm{E} \\
46^{\circ} 36^{\prime} \mathrm{N}, 10^{\circ} 25^{\prime} \mathrm{E}\end{array}$ \\
\hline
\end{tabular}

* above sea level 
Table 2. Syrphid species recorded by the two sampling methods (observation plot and line transect method) in three regions in 2015 The numbers indicate the total number of specimens recorded.

\begin{tabular}{|c|c|c|c|}
\hline \multirow[b]{2}{*}{ Species } & \multirow[b]{2}{*}{ Region } & \multicolumn{2}{|c|}{ Number of individuals } \\
\hline & & $\begin{array}{c}\text { Observation } \\
\text { plot }\end{array}$ & $\begin{array}{c}\text { Line } \\
\text { transect }\end{array}$ \\
\hline Caliprobola speciosa & Großes Walsertal & 1 & \\
\hline Cheilosia impressa & Val Müstair & 1 & \\
\hline Cheilosia personata & Eisenwurzen & & 1 \\
\hline Chrysotoxum cautum & Großes Walsertal & 1 & \\
\hline Chrysotoxum vernale & Großes Walsertal & 1 & \\
\hline Epistrophe diaphana & Großes Walsertal & 3 & \\
\hline \multirow{3}{*}{ Episyrphus balteatus } & Eisenwurzen & 7 & 1 \\
\hline & Val Müstair & 2 & \\
\hline & Großes Walsertal & 2 & \\
\hline Eristalis jugorum & Großes Walsertal & 2 & \\
\hline \multirow{2}{*}{ Eristalis tenax } & Eisenwurzen & 1 & 1 \\
\hline & Val Müstair & 1 & \\
\hline \multirow{3}{*}{ Eupeodes lapponicus } & Eisenwurzen & 18 & 2 \\
\hline & Val Müstair & 1 & \\
\hline & Großes Walsertal & 1 & \\
\hline \multirow{3}{*}{ Melanostoma mellinum } & Eisenwurzen & 2 & 4 \\
\hline & Val Müstair & 9 & 11 \\
\hline & Großes Walsertal & 13 & 10 \\
\hline Melanostoma scalare & Großes Walsertal & 1 & \\
\hline Merodon equestris & Eisenwurzen & 1 & 1 \\
\hline \multirow{2}{*}{ Myathropa florea } & Eisenwurzen & 1 & \\
\hline & Großes Walsertal & 1 & \\
\hline Orthonevra geniculata & Eisenwurzen & 1 & \\
\hline Parasyrphus annulatus & Val Müstair & 1 & \\
\hline Pelecocera tricincta & Großes Walsertal & 1 & \\
\hline Pipizella viduata & Eisenwurzen & & 1 \\
\hline \multirow{2}{*}{ Pipizella virens } & Eisenwurzen & & 1 \\
\hline & Großes Walsertal & 2 & \\
\hline Platycheirus albimanus & Val Müstair & 1 & \\
\hline Platycheirus sticticus & Val Müstair & 1 & \\
\hline Rhingia borealis & Eisenwurzen & 1 & \\
\hline Scaeva pyrastri & Val Müstair & 1 & \\
\hline \multirow{2}{*}{$\begin{array}{l}\text { Sphaerophoria } \\
\text { interrupta }\end{array}$} & Eisenwurzen & & 1 \\
\hline & Val Müstair & & 2 \\
\hline \multirow{3}{*}{ Sphaerophoria scripta } & Eisenwurzen & 4 & 11 \\
\hline & Val Müstair & 2 & 2 \\
\hline & Großes Walsertal & 6 & 1 \\
\hline Sphegina sibirica & Eisenwurzen & 2 & \\
\hline \multirow{2}{*}{ Syritta pipiens } & Eisenwurzen & 4 & \\
\hline & Val Müstair & 1 & 3 \\
\hline Syrphus ribesii & Eisenwurzen & 1 & \\
\hline \multirow{2}{*}{ Volucella bombylans } & Eisenwurzen & & 1 \\
\hline & Val Müstair & 2 & 1 \\
\hline
\end{tabular}

laboratory. They were preserved in $70 \%$ ethanol and identified using identification keys (Stubbs, 1983; Veen, 2010).

\section{Data analysis}

We checked the data for normal distribution graphically by creating QQ-plots. To evaluate differences in species richness and abundance we used linear mixed-effect models including sam-
Table 3. Syrphid species recorded using the two collection methods (observation plot and line transect method) in one region (Eisenwurzen) in 2016 . The numbers indicate the total number recorded.

\begin{tabular}{|c|c|c|}
\hline \multirow{2}{*}{ Species } & \multicolumn{2}{|c|}{ Number of individuals } \\
\hline & Observation plot & Line transect \\
\hline Cheilosia impressa & 1 & 1 \\
\hline Chrysotoxum bicinctum & 6 & \\
\hline Chrysotoxum octomaculatum & 1 & \\
\hline Episyrphus balteatus & 6 & \\
\hline Eristalis tenax & 1 & 1 \\
\hline Eristalis arbustorum & 3 & \\
\hline Eristalis jugorum & 1 & 1 \\
\hline Eristalis nemorum & 1 & \\
\hline Melanostoma mellinum & 24 & 3 \\
\hline Meliscaeva auricollis & 1 & \\
\hline Merodon equestris & & 1 \\
\hline Merodon rufus & 2 & \\
\hline Myathropa florea & 4 & \\
\hline Paragus haemorrhous & 1 & \\
\hline Parasyrphus lineolus & 1 & \\
\hline Pipiza noctiluca & 1 & \\
\hline Pipizella sp. & 2 & \\
\hline Pipizella viduata & 3 & 1 \\
\hline Pipizella virens & 1 & \\
\hline Sphaerophoria interrupta & 2 & \\
\hline Sphaerophoria scripta & 33 & 7 \\
\hline Sphaerophoria sp. & 1 & \\
\hline Syritta pipiens & 4 & \\
\hline Syrphus ribesii & 2 & \\
\hline
\end{tabular}

pling month and region as random factors for the 2015 data, and month and year as random factors for the 2015 and 2016 data recorded at Eisenwurzen. We also verified normality (Shapiro test) and homogeneity of variance (Fligner test) in each model. Pearson correlations were computed to determine covariance in the structure of the data. We performed statistical analysis in $\mathrm{R}$ version 3.3.1 (R Core Team, 2016) and used an alpha level of 0.05.

To assess the difference in species assemblages recorded using the line transect and observation plots, a principal coordinate analysis (PCO) based on a resemblance matrix of Bray-Curtis similarity was carried out (Leyer \& Wesche, 2007). A permutational ANOVA (PERMANOVA) was computed to test for significant differences in species assemblages recorded using the two methods (Anderson et al., 2008). SIMPER-routine (similarity percentages) was used to determine the role of individual species in contributing to the difference in the results recorded using the two sampling methods, which decomposes average Bray-Curtis dissimilarities between all samples into the percentage contribution from each species (Anderson et al., 2008). Time and region were included in the PERMANOVA model to account for the variations in the two sampling methods (Öberg et al., 2007). Measures of resemblance among different species assemblages were made using Bray-Curtis resemblance (Somerfield, 2008). SIMPER, PERMANOVA and PCO were done using the Primer

Table 4. PERMANOVA table showing the effect of two sampling methods, month, region and interaction on syrphid species assemblages in 2015. Significant effects are shown in bold.

\begin{tabular}{|c|c|c|c|c|c|c|}
\hline Source & df & SS & MS & Pseudo-F & $\mathrm{P}($ perm $)$ & Unique perms \\
\hline Sampling method & 1 & 2877.8 & 2877.8 & 3.3116 & 0.0091 & 9941 \\
\hline Month & 1 & 3607.9 & 3607.9 & 4.1517 & 0.0020 & 9952 \\
\hline Region & 2 & 5411.7 & 2705.9 & 3.1137 & 0.0011 & 9934 \\
\hline Month $\times$ Region & 2 & 7154.5 & 3577.2 & 4.1164 & 0.0002 & 9924 \\
\hline Month $\times$ Sampling method & 1 & 487.14 & 487.14 & 0.56055 & 0.7508 & 9952 \\
\hline Region $\times$ sampling method & 2 & 2324 & 1162 & 1.3372 & 0.2037 & 9921 \\
\hline Month $\times$ Region $\times$ Sampling method & 2 & 2259.5 & 1129.8 & 1.3 & 0.2297 & 9944 \\
\hline
\end{tabular}


(a)

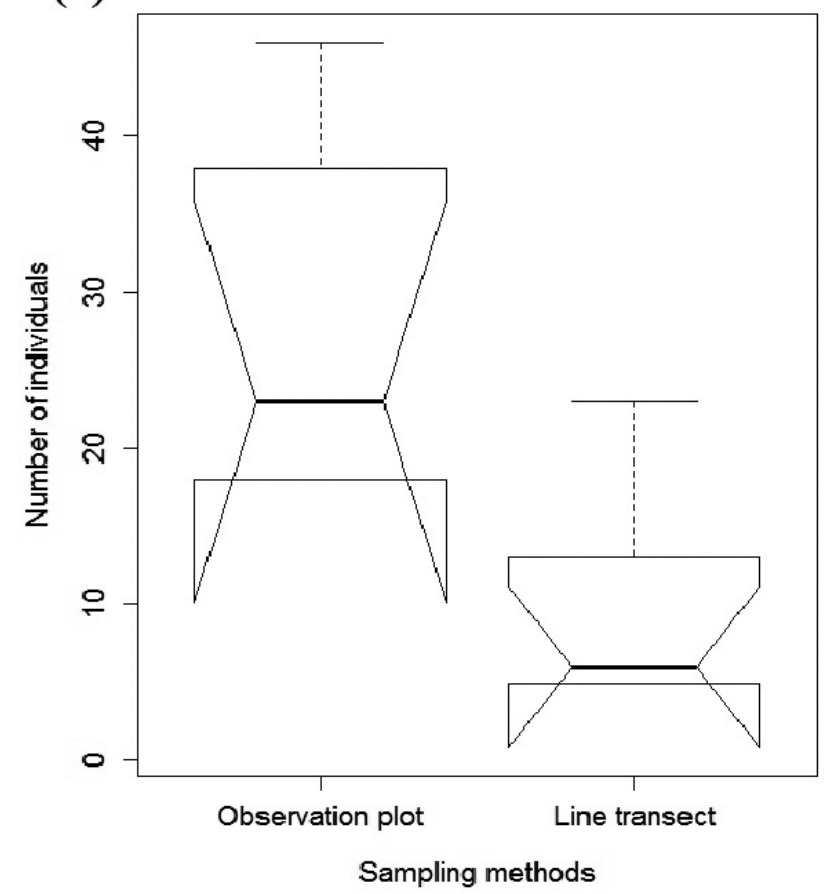

(b)

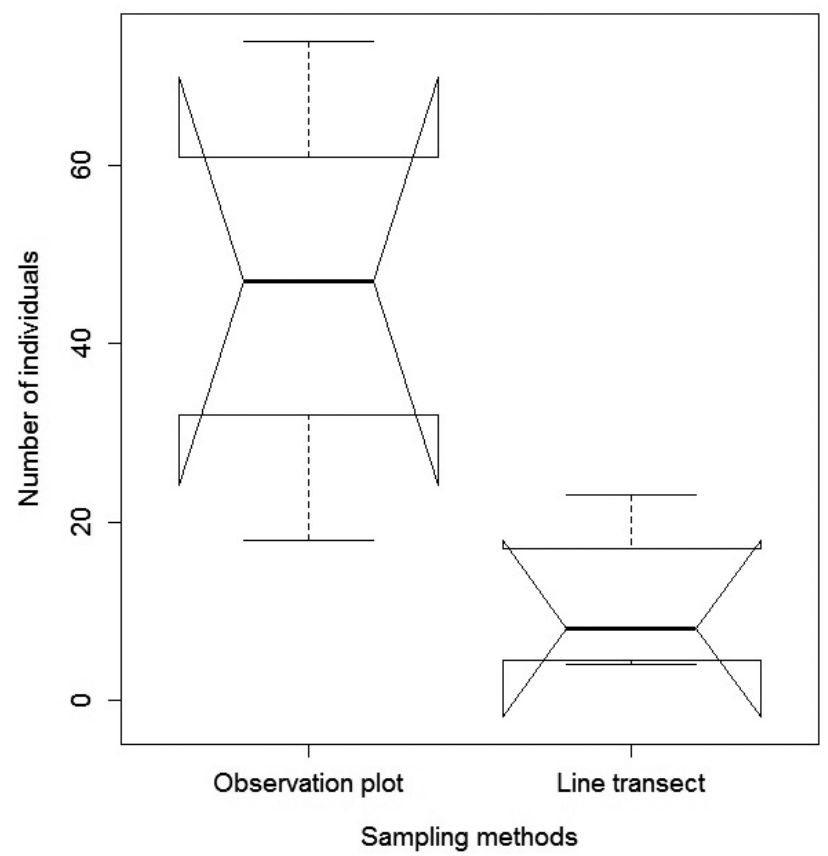

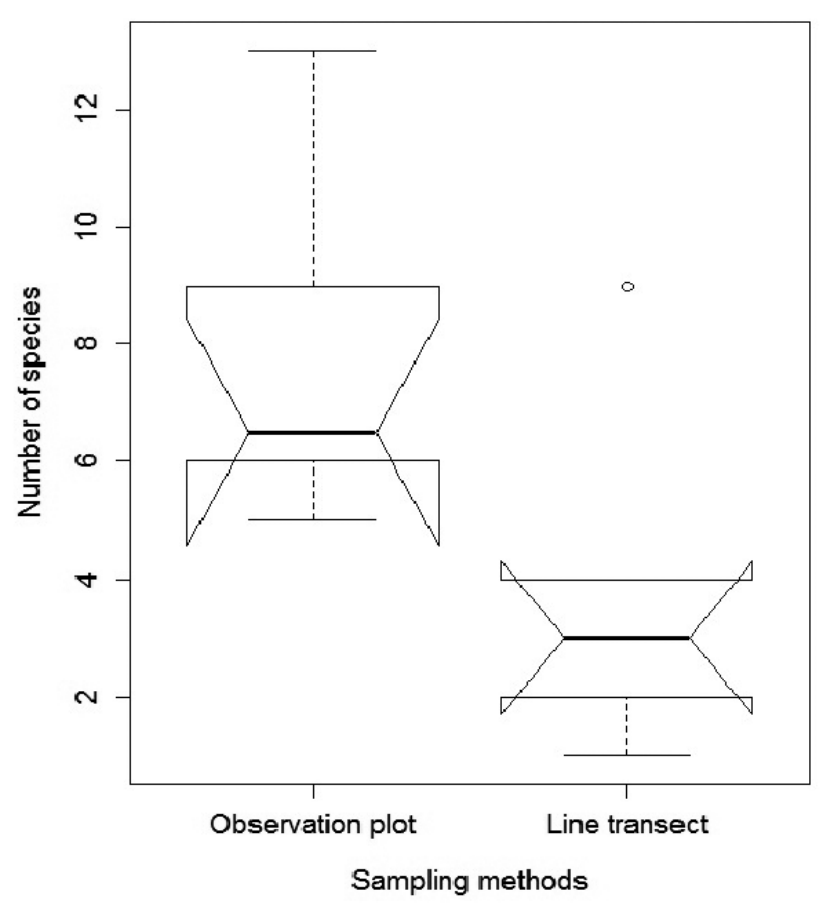

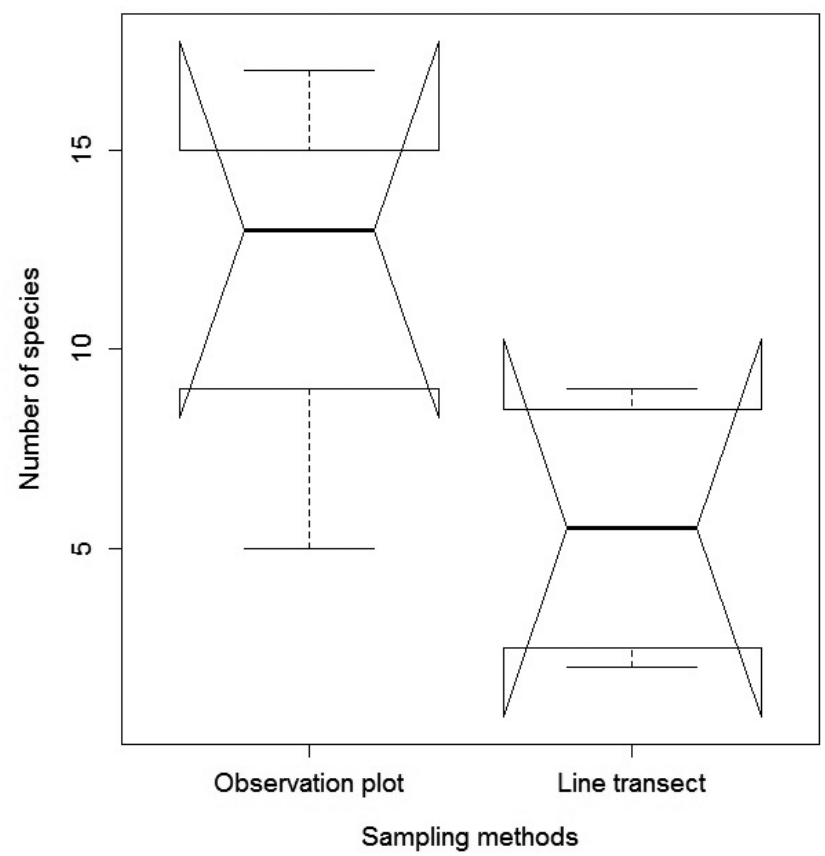

Fig. 2. Syrphid abundance and richness recorded by two sampling methods in (a) the three regions Eisenwurzen, Großes Walsertal and Val Müstair in 2015 and (b) one region Eisenwurzen in 2015 and 2016 . Boxplots show the medians, the $25 \%$ and $75 \%$ percentiles and the $10 \%$ and $90 \%$ percentiles (indicated as dashed lines), and notches.

version 6.1.13 with PERMANOVA+ (PRIME-E Ltd., Plymouth, UK).

\section{RESULTS}

Overall, 361 individuals and 41 species belonging to 26 genera were recorded using the two methods over the course of two years. In 2015, a total of 224 individuals belonging to 29 species and 23 genera were recorded in the three regions. 26 species were recorded in the observa- tion plots and 12 species along the line transects (Table 2). In 2016, 137 individuals belonging to 24 species and 16 genera were recorded at Eisenwurzen. 23 species were recorded in the observation plots and seven species along the line transects (Table 3).

A significantly higher abundance $(t=3.174, \mathrm{df}=1, \mathrm{p}$ $=0.001)$ and richness of syrphids $(t=3.076, \mathrm{df}=1, \mathrm{p}=$ 0.002 ) was recorded in observation plots than along the line transects in 2015 (Fig. 2a). Eupeodes lapponicus and 

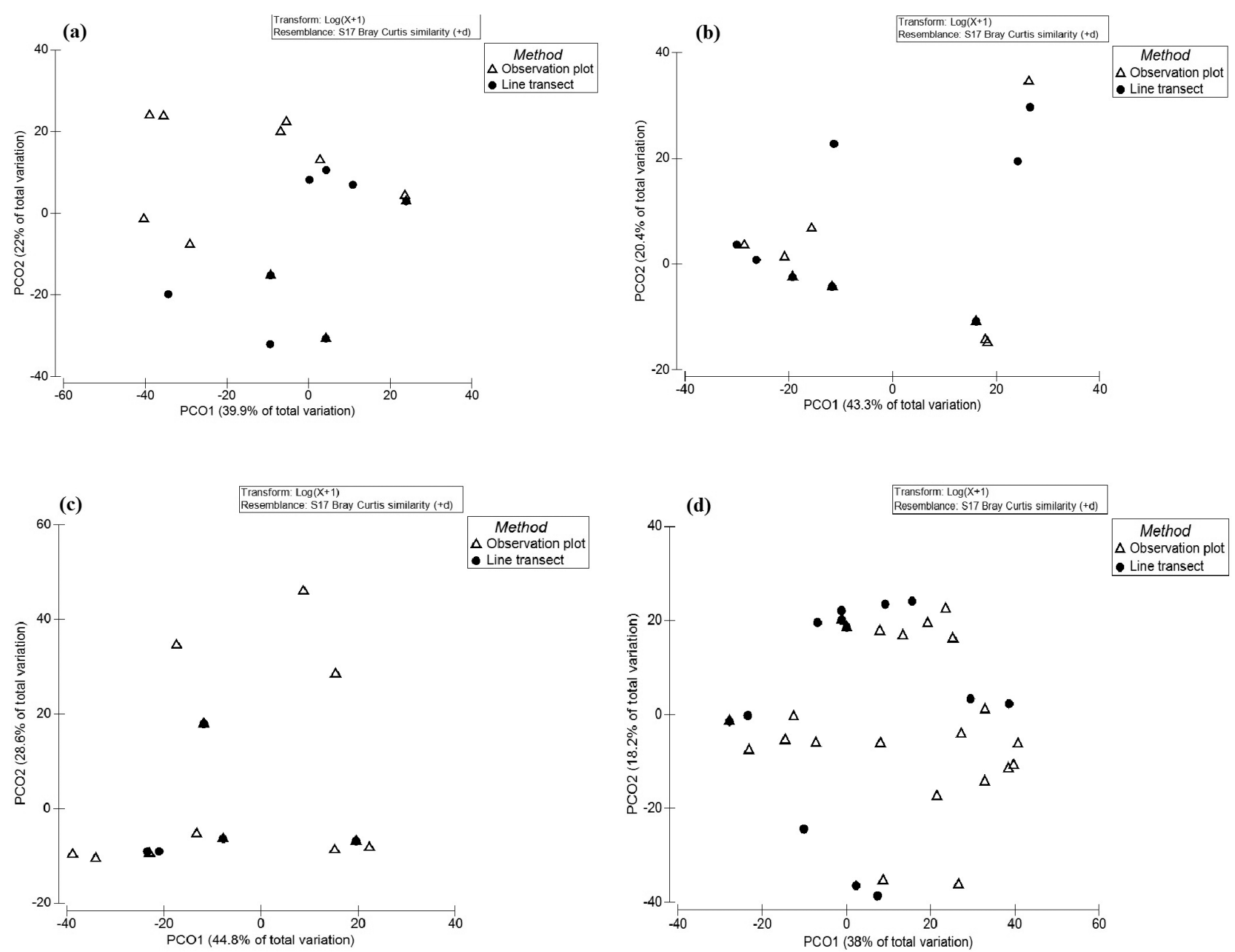

Fig. 3. Principal coordinate analysis (PCO) showing the distribution of syrphid species assemblages recorded by the two sampling methods (Observation plot and line transect) in the regions (a) Eisenwurzen, (b) Val Müstair and (c) Großes Walsertal in 2015. PCO showing species assemblages in one region (Eisenwurzen) in 2015 and 2016 (d).

Melanostoma mellinum were the most abundant species in 2015. Comparing data for one region (Eisenwurzen) in 2015 and 2016, revealed similar results (Fig. 2b). In addition, syrphid abundance $(t=2.919, \mathrm{df}=1, \mathrm{p}=0.003)$ and richness $(t=2.118, \mathrm{df}=1, \mathrm{p}=0.034)$ were significantly higher in the observation plots. Again, M. mellinum and, in addition, Sphaerophoria scripta were the most abundant species in 2016.

Significantly different species assemblages were recorded using the two sampling methods (Table 4, 5). Syrphid species assemblages in 2015 were significantly affected by sampling method, month and region (Table 4). There was also a significant interaction between month and region
(Fig. 3a, b, c). Separation of species assemblages recorded using the two sampling methods was revealed by PCO for the region Eisenwurzen in 2015 and 2016 (Fig. 3d). In addition, there were significant effects of sampling method, month and year, including a significant interaction between month and year, on species assemblages in the region Eisenwurzen in 2015 and 2016 (Table 5).

Four species (M. mellinum, S. scripta, Episyrphus balteatus and E. lapponicus) accounted for $95.43 \%$ of the similarity in the species assemblages recorded for the observation plots and two species (M. mellinum and S. scripta) accounted for $96.22 \%$ of in the similarity in the records for the line transects. The average dissimilarity of $70.58 \%$

Table 5. PERMANOVA table showing the effect of two sampling methods, months, year (2015 and 2016) and interaction on syrphid species assemblages in one region (Eisenwurzen). Significant effects are shown in bold.

\begin{tabular}{lcccccc}
\hline Source & df & SS & MS & Pseudo-F & P(perm) & Unique perms \\
\hline Sampling method & 1 & 8230.3 & 8230.3 & 8.0317 & $\mathbf{0 . 0 0 0 1}$ & 9930 \\
Month & 1 & 5377.2 & 5377.2 & 5.2475 & $\mathbf{0 . 0 0 0 1}$ & 9952 \\
Year & 1 & 4470 & 4470 & 4.3621 & $\mathbf{0 . 0 0 0 4}$ & 9956 \\
Month $\times$ Year & 1 & 4021.6 & 4021.6 & 3.9245 & $\mathbf{0 . 0 0 2 0}$ & 9936 \\
Month $\times$ Sampling method & 1 & 853.65 & 853.65 & 0.83305 & 0.5473 & 9944 \\
Year $\times$ Sampling method & 1 & 4555.4 & 4555.4 & 4.4455 & $\mathbf{0 . 0 0 1 0}$ & 9945 \\
Month $\times$ Year $\times$ Sampling method & 1 & 853.08 & 853.08 & 0.83249 & 0.5475 & 9953 \\
\hline
\end{tabular}


in the species assemblages recorded using the two methods was due differences in the incidences of five species (S. scripta, M. mellinum, E. balteatus, L. lapponicus and Syritta pipiens).

\section{DISCUSSION}

Our results show that the observation plot method is the best for determining abundance and richness of syrphids. Neither of the two methods recorded all the species but the observation plot method recorded more individuals and more of the species occurring in the study regions. During the periods of time (15 min) spent at each plot it is likely observer became part of the background and after a while syrphids were not disturbed by the collector and became active again. In contrast, continuous sweep netting along a line transect might have disturbed the syrphids and caused them to fly away.

Syrphids are very active pollinators and react quickly (Kühn et al., 2006). Species like E. balteatus, Myathropa florea and Syrphus ribesii, which were almost exclusively recorded in observation plots, tended to hover near the ground and fly through vegetation (Speight, 2014), where they could easily be observed but possibly not recorded by the line transect method. Differences in the syrphid assemblages between months and regions are usually interpreted in terms of environmental requirements (Hawkins et al., 2003), including temperature regimes and overwintering sites. For example, S. ribesii (Hart \& Bale, 1997) is very tolerant of frost and the overwintering ability of E. balteatus is strongly related to restricted cold-hardiness (Hondelmann \& Poehling, 2007). In addition, geographic environmental variables (altitude, latitude and longitude) are known to affect species assemblages (Keil \& Konvicka, 2005) and may account for the significant regional effect recorded in 2015. Moreover, the significant method and year interaction indicates that both methods should be used if the aim is to collect as many species and individuals as possible.

Though the area sampled by the observation plot method $\left(4 \times 2=8 \mathrm{~m}^{2}\right)$ was less than a tenth of that sampled by the line transect method $\left(2 \times 15 \times 3=90 \mathrm{~m}^{2}\right)$, significantly more species and individuals were recorded by this method. Based on the current study, the observation plot method seemed to be better than the line transect method for several reasons. First, by using the observation plot method the observer only records the animal group of interest, i.e. syrphids. In contrast, in using methods like yellow pan traps, Malaise traps or the line transect method other insects are also killed, which is contrary to insect conservation (Costello et al., 2016). Second, the observation plot method is better in very sensitive ecosystems because smaller areas are disturbed by the survey.

Overall, this study should help in selecting the appropriate sampling techniques for assessing syrphids in alpine grasslands at different altitudes. The observation plot method was shown to be more appropriate in terms of recording more grassland species of syrphids and individuals. This method appears to be adequate for studies that aim to compare differences in syrphid numbers between various grassland habitats. The observation plot method is the best providing the observers have a good knowledge of syrphids and are able to identify them to species in the field.

ACKNOWLEDGEMENTS. This study was supported by the Austrian Academy of Sciences (project: Healthy Alps, project number: 10470). Thanks to M. Suarez-Rubio for statistical advice. Special thanks to the farmers and land owners for their permission to conduct investigations on their meadows.

\section{REFERENCES}

Anderson M.J., Gorley R.N. \& Clarke R.K. 2008: Permanova + for Primer: Guide to Software and Statisticl Methods. PRIMER-E, Plymouth, $214 \mathrm{pp}$.

Burgio G. \& Sommaggio D. 2007: Syrphids as landscape bioindicators in Italian agroecosystems. - Agric. Ecosyst. Environ. 120: $416-422$.

Cane J.H., Minckley R.L. \& Kervin L.J. 2000: Sampling bees (Hymenoptera: Apiformes) for pollinator community studies: pitfalls of pan-trapping. - J. Kans. Entomol. Soc. 73: 225-231.

Costello M.J., Beard K.H., Corlett R.T., Cumming G.S., Devictor V., Loyola R., Maas B., Miller-Rushing A.J., Pakeman R. \& PrIMACK R.B. 2016: Field work ethics in biological research. - Biol. Conserv. 203: 268-271.

FRANK T. 1999: Density of adult hoverflies (Dipt., Syrphidae) in sown weed strips and adjacent fields. - J. Appl. Entomol. 123: 351-355.

García-López A., Micó E., Zumbado M.A. \& Galante E. 2011: Sampling scarab beetles in tropical forests: The effect of light source and night sampling periods. - J. Insect Sci. 11: 1-14.

Haenke S., Scheid B., Schaefer M., Tscharntke T. \& Thies C. 2009: Increasing syrphid fly diversity and density in sown flower strips within simple vs. complex landscapes. - J. Appl. Ecol. 46: 1106-1114.

HART A.J. \& BALE J.S. 1997: Evidence for the first strongly freeze-tolerant insect found in the UK. - Ecol. Entomol. 22: 242-245.

Hawkins B.A., Field R., Cornell H.V., Currie D.J., Guégan J.F., Kaufman D.M., Kerr J.T., Mittelbach G.G., Oberdorff T., O'Brien E.M. \& Porter E.E. 2003: Energy, water, and broadscale geographic patterns of species richness. - Ecology 84 : 3105-3117.

Hickman J.M., Wratten S.D., Jepson P.C. \& Frampton C.M. 2001: Effect of hunger on yellow water trap catches of hoverfly (Diptera: Syrphidae) adults. - Agr. For. Entomol. 3: 35-40.

Hondelmann P. \& Poenling H.M. 2007: Diapause and overwintering of the hoverfly Episyrphus balteatus. - Entomol. Exp. Appl. 124: 189-200.

Hussain R.I., Walcher R., Brandl D., Jernej I., Arnberger A., ZALLER J.G. \& FRANK T. 2017: Influence of abandonment on syrphid assemblages in mountainous meadows. - J. Appl. Entomol. doi.org/10.1111/jen.12482

KeIL P. \& Konvicka M. 2005: Local species richness of Central European hoverflies (Diptera: Syrphidae): a lesson taught by local faunal lists. - Divers. Distrib. 11: 417-426.

Kohlmann B. 2011: Biodiversity conservation in Costa Rica - An animal and plant biodiversity atlas models and applications. In I.Ya. Pavlinov (ed.): Research in Biodiversity-Models and Applications. InTech, Rijeka, pp. 203-222.

Kühn J., Hamm A., Schindler M. \& WitTMann D. 2006: Ressourcenaufteilung zwischen der oligolektischen Blattschneiderbiene Megachile lapponica L. (Hymenoptera, Apiformes) und 
anderen Blütenbesuchern am schmalblättrigen Weidenröschen (Epilobium angustifolium, Onagraceae). - Mitt. Dt. Ges. Allgem. Angew. Entomol. 15: 389-392.

LeYer I. \& Wesche K. 2007: Multivariate Statistik in der Ökologie. Springer, Berlin, Heidelberg, 221 pp.

Marcos-García M.A., García-López A., Zumbado M.A. \& RotherAy G.E. 2012: Sampling methods for assessing syrphid biodiversity (Diptera: Syrphidae) in tropical forests. - Envir. Entomol. 41: 1544-1552.

Mudri-Stojnić S., Andrić A., Jozan Z. \& Vujić A. 2012: Pollinator diversity (Hymenoptera and Diptera) in semi-natural habitats in Serbia during summer. - Arch. Biol. Sci. 64: 777-786.

NAmaghi H.S. \& Husseini M. 2009: The effects of collection methods on species diversity of family Syrphidae (Diptera) in Neyshabur, Iran. - J. Agr. Sci. Tech. 11: 521-526.

ÖвеRG S., Еквом B. \& Bommarco R. 2007: Influence of habitat type and surrounding landscape on spider diversity in Swedish agroecosystems. - Agr. Ecosyst. Environ. 122: 211-219.

Petanidou T., Vujić A. \& Ellis W.N. 2011: Hoverfly diversity (Diptera: Syrphidae) in a Mediterranean scrub community near Athens, Greece. - Ann. Soc. Entomol. Fr. 47: 168-175.

Pimm S.L., Russell G.J., Gittleman J.L. \& Brooks T.M. 1995: The future of biodiversity. - Science 269: 347-350.

Power E.F., Jackson Z. \& Stout J.C. 2016: Organic farming and landscape factors affect abundance and richness of hoverflies (Diptera, Syrphidae) in grasslands. - Insect Conserv. Diver. 9: 244-253.

R Core TeAm 2016: $R$ : A Language and Environment for Statistical Computing (Ver. v 3.1.1). URL: http://www.R-project.org.

Ricarte S.A. \& Marcos-García M.Á. 2008: Los sírfidos (Diptera: Syrphidae) del Parque Nacional de Cabañeros (España) una herramienta para la gestión. - Bol. Asoc. Esp. Entomol. 32: 19-32.
Schweiger O., Musche M., Bailey D., Billeter R., Diekötter T., Hendrickx F., Herzog F., Liira J., Maelfait J.P., Speelmans M. \& Dzıock F. 2007: Functional richness of local hoverfly communities (Diptera, Syrphidae) in response to land use across temperate Europe. - Oikos 116: 461-472.

Soвota G. \& TWARDOWSKi J. 2004: Variation in species spectrum of hoverflies (Diptera, Syrphidae) in arable crops depending on the collection method. - Electron. J. Pol. Agr. Univ. (Biol.) 7(2): 8.

Somerfield P.J. 2008: Identification of the Bray-Curtis similarity index: Comment on Yoshioka (2008). - Marine Ecol. Progr. Ser. 372: 303-306.

SommagGio D. 1999: Syrphidae: can they be used as environmental bioindicators? - Agr. Ecosyst. Environ. 74: 343-356.

SpEIGHT M.C.D. 2014: Species accounts of European Syrphidae (Diptera), 2014. Syrph the Net, the Database of European Syrphidae, Vol. 78. Dublin, $321 \mathrm{pp.}$

StuBBs A. 1983: British Hoverflies: An Illustrated Identification Guide. British Entomological and Natural History Society, London, 469 pp.

VeEN M.P.V. 2010: Hoverflies of Northwest Europe: Identification Keys to the Syrphidae. KNNV, Utrecht, $256 \mathrm{pp}$.

Walcher R., Karrer J., Sachslehner L., Bohner A., Pachinger B., Brandl D., Zaller J.G., Arnberger A. \& FranK T. 2017: Diversity of bumblebees, heteropteran bugs and grasshoppers maintained by both: abandonment and extensive management of mountain meadows in three regions across the Austrian and Swiss Alps. — Landsc. Ecol. 32: 1937-1951.

Received January 13, 2018; revised and accepted March 28, 2018 Published online April 9, 2018 